\title{
ANALYSIS OF DISPOSAL OF PUBLIC PROPERTY WITHOUT TENDER PROCEDURE ON THE EXAMPLE OF THE MUNICIPALITY OF KRAKOW
}

\author{
Anna Trembecka, PhD \\ Faculty of Mining Surveying and Environmental Engineering \\ AGH University of Science and Technology \\ e-mail:trembec@agh.edu.pl
}

\begin{abstract}
The aim of this study is to analyze the procedure for the disposal of public property without tender on the example of the Municipality of Krakow, with respect to the scope, purpose, conditions of disposal and generated income, in the period of 2012 -2014.

The vast majority of plots of land (over 220) were disposed of in order to improve the land use conditions of an adjacent plot, subject to ownership rights or to perpetual usufruct of a person who intended to purchase this property.

The mode of disposal without tender procedures is also widely used for those who are entitled to the priority right in the acquisition of public property. This category includes, for example, residential tenants who, during the analyzed period, purchased about 2.8 thousand dwellings, in most cases with a 90 -percent discount.

The article points out the problems which occur over the course of preparing documentation necessary for the transaction, in particular those concerning incorrect geodetic and legal status of the real property. The author discussed selected case law on this subject and proposed methods of solving these problems.
\end{abstract}

Key words: real estate, procedure, disposal of public property.

JEL Classification: R 52.

Citation: Trembecka A., 2016, Analysis of Disposal of Public Property Without Tender Procedure on the Example of the Municipality of Krakow, Real Estate Management and Valuation, Vol. 24, No. 2, pp. 5-12.

DOI: 10.1515/remav-2016-0009

\section{Introduction}

The primary mode of disposal of public property is a tender procedure. The mode without such a procedure must be based on specific circumstances which allow for such a possibility under the Real Estate Management Act.

The disposal should be understood as defined in Art. 4 Clause 3b of the Real Estate Management Act, which is carrying out legal actions resulting in the transfer of ownership of real estate or the transfer of perpetual usufruct of a plot of land, or letting the land for perpetual usufruct. The most commonly applied forms of disposal of real estate owned by the State Treasury or local governments is sale and letting the land for perpetual usufruct.

The performed studies relate to the process of disposal without a tender procedure of real estate owned by the Municipality of Krakow in the period of 2012-2014. The scope of the sold real estate (number of cadastral parcels, surface area, number of dwelling units) was specifically analyzed, as well as the purposes behind selling and entities for the benefit of whom the properties were sold, and also the generated income.

The source material was data from the Department of the Treasury of the Municipality of Krakow, 
legislation, literature and related case law.

\section{Permissibility for the disposal of public property without tender procedure}

The disposal of the real estate owned by the State Treasury or local government units without a tender procedure is permitted under exceptional circumstances in the cases enumerated in Art. 37 Section 2 of the Real Estate Management Act (Act 1997) without the possibility of their broader interpretation (GDESZ, TREMBECKA 2013). Under this provision, real property is sold without a tender procedure if:

1) it is sold to a person with a priority right to the acquisition of public property, pursuant to Art. 34 (Act, 1997)

2) the disposal takes place between the State Treasury and local government units, and between these units;

3) it is sold to individuals and legal persons engaged in charity, welfare and care, culture, healthcare, education, scientific activities, research and development, sport or travel, nonprofit activities, as well as to public benefit organizations for public benefit activities;

4) the disposal is made by way of exchange or donation;

5) the sale of the real estate is to its perpetual user;

6) the subject of the disposal is real property or parts thereof that may improve the land use conditions of an adjacent plot, subject to ownership rights or to perpetual usufruct of the person who intends to purchase this property or part thereof, if they cannot be used as separate properties (a so-called "complement");

7) it is intended as a contribution in kind to a company, or as assets of a newly established legal person of the state or local government, or the property of a foundation being established;

8) it is disposed of for the benefit of an entity managing a special economic zone, being located on its territory;

9) the subject of disposal is a share in the real estate, and the disposal is to other co-owners of the real estate;

10) it is sold for the benefit of churches and religious associations that have governed relationship with the state, for the purposes of religious activities;

11) it is sold to a private partner or company referred to in Art. 14 Section 1 of the Act of 19 December 2008 on public and private partnership, if the sale constitutes the own contribution of a public entity;

12) it is sold to diplomatic missions or consular offices of foreign states, as well as other equivalent agencies and institutions, in terms of privileges and immunities under the acts of law, international agreements, or commonly binding international practice;

13) it is sold to an investor who carries an investment in the construction of a nuclear power facility in accordance with the provisions of the Act (Act 2011);

14) it is sold to an investor who carries an investment in the construction of an airport terminal or accompanying investment, in accordance with the provisions of the Act (Act 2009).

In addition, with the approval of the Governor, there is a possibility of optional exemption from tender procedures regarding properties owned by the State Treasury and the council or regional council, respectively, as to the property owned by local government units in the case of:

1) the disposal of the real property for housing development, or for the implementation of technical infrastructure facilities, or for other public purposes, if these objectives will be implemented by the entities for whom they constitute statutory objectives, and whose income is spent entirely on the statutory activities,

2) the sale of real property to a lessee of this property under an agreement concluded for at least 10 years, if the real property has been developed on the basis of a construction permit.

Exemption from the tendering mode is discretionary and must be granted individually in each case. This mode cannot be used if more than one entity that meets the above conditions applies for the acquisition of the specific real estate (JAWORSKI et al. 2009).

\section{The scope of the real estate owned by the Municipality of Krakow sold without tender procedures}

As of 1 January 2014, the total area of land owned by the Municipality of Krakow or held in perpetual usufruct, was 7,752 hectares, with $42 \%$ being areas for transportation. 
In the period of 2012-2014, as part of the real estate management procedures, the Municipality disposed of a total of 259 parcels with a total area of 10.2237 hectares without tender procedures, including the sale of 207 plots with the total area of 9.0417 ha, and 52 plots with a total area of 1.1820 ha let for perpetual usufruct. The total income generated from the sale of these plots of land amounted to approx. 23.2 million PLN, and from the first annual payments for perpetual usufruct (fixed at $25 \%$ of the real estate price) reached approx. 1 million PLN. The total income from the disposal of the plots of land without tender procedures amounted to approx. 24.2 million PLN.

The number, area and price of the plots of land sold by the Municipality of Krakow between 2012 and 2014 without tender procedure have been presented in Table 1.

Table 1

The number, area and price of the plots of land sold by the Municipality of Krakow between 2012 and 2014 without a tender procedure

\begin{tabular}{|c|c|c|c|c|c|c|}
\hline \multirow[t]{2}{*}{ Period } & \multirow[t]{2}{*}{$\begin{array}{l}\text { Form of } \\
\text { disposal }\end{array}$} & \multirow[t]{2}{*}{$\begin{array}{l}\text { Number } \\
\text { of plots }\end{array}$} & \multirow[t]{2}{*}{$\begin{array}{c}\text { Plot area } \\
\text { (ha) }\end{array}$} & \multirow{2}{*}{$\begin{array}{c}\text { Total area } \\
\text { of plots } \\
\text { disposed } \\
\text { of in a } \\
\text { given } \\
\text { year }\end{array}$} & $\begin{array}{l}\text { Price of real } \\
\text { property } \\
(\text { PLN })\end{array}$ & \multirow[t]{2}{*}{$\begin{array}{l}\text { Total price for the } \\
\text { plots of land } \\
\text { (PLN) }\end{array}$} \\
\hline & & & & & $\begin{array}{l}\text { First annual } \\
\text { payment for } \\
\text { perpetual } \\
\text { usufruct } \\
\text { (PLN) }\end{array}$ & \\
\hline \multirow[t]{2}{*}{2012} & Sale & 71 & 2.8022 & \multirow[t]{2}{*}{3.7742} & 15302392.93 & \multirow[t]{2}{*}{$16,126,519$} \\
\hline & $\begin{array}{l}\text { Letting for } \\
\text { perpetual } \\
\text { usufruct }\end{array}$ & 31 & 0.9720 & & $824,126.94$ & \\
\hline \multirow[t]{2}{*}{2013} & Sale & 75 & 5.3378 & \multirow[t]{2}{*}{5.4236} & $4,691,216.24$ & \multirow[t]{2}{*}{$4,797,295$} \\
\hline & $\begin{array}{c}\text { Letting for } \\
\text { perpetual } \\
\text { usufruct }\end{array}$ & 11 & 0.0858 & & $106,079.15$ & \\
\hline \multirow[t]{3}{*}{2014} & Sale & 61 & 0.9017 & \multirow[t]{2}{*}{1.0457} & $3,163126.94$ & \multirow[t]{2}{*}{$3,251,580$} \\
\hline & $\begin{array}{c}\text { Letting for } \\
\text { perpetual } \\
\text { usufruct }\end{array}$ & 10 & 0.1242 & & $88,453.88$ & \\
\hline & Total & 259 & \multicolumn{2}{|c|}{10.2237} & \multicolumn{2}{|c|}{$24,175,394$} \\
\hline
\end{tabular}

\subsection{Disposal for improving the land use conditions of an adjacent plot}

The vast majority of cadastral parcels (i.e. 208) were sold by the Municipality of Krakow in order to improve the land use conditions of an adjacent plot, based on (Art. 37 Section 2 Clause 6) (Act, 1997).

The condition for applying this legal standard is the simultaneous occurrence of three prerequisites:

1) the real property is to facilitate the improvement of the land use of only one adjacent real estate,

2) the owner or perpetual usufructuary is willing to purchase the property,

3) the real property intended for disposal cannot be developed as a separate property.

This mode is an option only when a single person is interested in the purchase. In such a situation, organizing a tender would be unjustified. If, however, more people are interested and the sold real estate or part thereof may have a functional relationship with more than one adjacent property, such a mode of sale is not permitted. This stems from the case law of the administrative court (Supreme Court judgment of 2006, Supreme Court judgment of 2009).

The most important issue in deciding whether a particular parcel can be sold without tender procedure, pursuant to Art. 37 Section 2 Clause 6 (Act 1997), is whether there are other real properties where the owners, under such provision, would have the right to apply to the authority to sell the real property so that the land use conditions of their own property could be improved. 
The plots of land sold in this mode by the Municipality of Krakow were mainly characterized by a small area (from 0.0020 ha to $0.0300 \mathrm{ha}$ ) and unfavorable shape, which made it impossible for them to be developed as separate real properties. These lands were often occupied without a legal title, and therefore, their disposal helped to settle the legal and surveying status of the properties and improve the spatial structure of the area.

Table 2

The number and area of plots of land sold by the Municipality of Krakow in order to improve the land use conditions of a neighboring property, and the income generated

\begin{tabular}{|c|c|c|c|c|c|c|}
\hline Period & $\begin{array}{l}\text { Form of } \\
\text { disposal }\end{array}$ & $\begin{array}{l}\text { Number } \\
\text { of plots }\end{array}$ & $\begin{array}{c}\text { Plot area } \\
\text { (ha) }\end{array}$ & $\begin{array}{c}\text { Total area } \\
\text { of plots } \\
\text { disposed } \\
\text { of in a } \\
\text { given } \\
\text { year }\end{array}$ & $\begin{array}{l}\text { Price of real } \\
\text { property } \\
\text { (PLN) } \\
\text { first annual } \\
\text { payment for } \\
\text { perpetual } \\
\text { usufruct } \\
\text { (PLN) }\end{array}$ & $\begin{array}{c}\text { Total income } \\
\text { generated from the } \\
\text { disposal of the real } \\
\text { properties } \\
\text { (PLN) }\end{array}$ \\
\hline \multirow{2}{*}{2012} & Sale & 66 & 1.0379 & \multirow{2}{*}{1.3866} & $3,277,274.5$ & \multirow[t]{2}{*}{$3,588,964$} \\
\hline & $\begin{array}{c}\text { Letting for } \\
\text { perpetual } \\
\text { usufruct }\end{array}$ & 29 & 0.3487 & & $311,690.43$ & \\
\hline \multirow[t]{2}{*}{2013} & Sale & 50 & 1.7410 & \multirow[t]{2}{*}{1.8268} & $2,853,952.01$ & \multirow[t]{2}{*}{$2,960,031$} \\
\hline & $\begin{array}{c}\text { Letting for } \\
\text { perpetual } \\
\text { usufruct }\end{array}$ & 11 & 0.0858 & & $106,079.15$ & \\
\hline \multirow[t]{3}{*}{2014} & Sale & 56 & 0.7755 & \multirow[t]{2}{*}{0.8997} & $3,099780.1$ & \multirow[t]{2}{*}{$3,188,233$} \\
\hline & $\begin{array}{c}\text { Letting for } \\
\text { perpetual } \\
\text { usufruct }\end{array}$ & 10 & 0.1242 & & $88,453.88$ & \\
\hline & Total & 225 & & & & 7,228 \\
\hline
\end{tabular}

Source: own study.

\subsection{Other cases of disposal of land parcels without tender procedure}

Relatively few, i.e. 37 cadastral parcels, were sold for other purposes, such as cultural, healthcare, scientific activities, for non-profit purposes, to the State Treasury, managing a special economic zone, churches, perpetual users and tenants. In these cases, the qualifications of the entity who is to purchase the land decide about the possibility of applying for disposal without tender procedures.

Despite the small number of land plots (compared to 225 plots sold to improve land use conditions of adjacent properties), the total area of such sales is 6.1304 ha. This is due to the fact that the plots sold to enlarge adjacent real properties are generally characterized by small areas.

The largest area of land, i.e. 1.9652 hectares, was sold to the State Treasury, second was land sold to entities who run cultural, healthcare or scientific activities with an area of 1.8438 hectares, followed by 1.6547 hectares of land sold to an entity managing a special economic zone.

The highest price of approx. 11.3 million PLN was obtained from the sale of land to the manager of a special economic zone. On the other hand, despite the large area of land sold to the Treasury, its price was set at a low level, i.e. at approx. 0.85 million PLN. This is due to the discount rate granted by the Municipality of Krakow.

The data on the number of parcels of the Municipality of Krakow sold without tender procedure to individual entities, their area and their price, have been illustrated in Table 3, whereas Table 4 contains the aforementioned figures divided into individual years in the period 2012-2014.

Eight contracts were concluded for the sale of real estate to perpetual users, which resulted in the expiry of the right of perpetual usufruct, and separate ownership of the building structures and equipment located on the land.

Expiry of the right of perpetual usufruct does not require it to be removed from the land and mortgage register. The right shall automatically expire upon the conclusion of a sale agreement. 
Table 3

The number, area and price of land plots sold by the Municipality of Krakow to individual entities without a tender procedure

\begin{tabular}{|c|c|c|c|}
\hline $\begin{array}{c}\text { Entity, for the benefit } \\
\text { of whom the property } \\
\text { was disposed of }\end{array}$ & Number of plots & $\begin{array}{c}\text { Area of land } \\
\text { (ha) }\end{array}$ & $\begin{array}{l}\text { Total income from the } \\
\text { disposal of real estate } \\
\text { (PLN) }\end{array}$ \\
\hline $\begin{array}{c}\text { Entities who run } \\
\text { charity, welfare and } \\
\text { care, cultural, } \\
\text { healthcare, scientific, } \\
\text { non-profit activities }\end{array}$ & 9 & 1.8438 & $1,381,792$ \\
\hline State Treasury & 9 & 1.9652 & 857,082 \\
\hline $\begin{array}{c}\text { Entity managing a } \\
\text { special economic zone } \\
\text { where the real } \\
\text { property is located }\end{array}$ & 2 & 1.6547 & $11,284,988$ \\
\hline $\begin{array}{l}\text { Churches having } \\
\text { settled relations with } \\
\text { the state, for the } \\
\text { purposes of religious } \\
\text { activities }\end{array}$ & 8 & 0.4309 & 363,696 \\
\hline Perpetual users & 8 & 0.2936 & 539,475 \\
\hline $\begin{array}{l}\text { Lessee of the property } \\
\text { under an agreement } \\
\text { concluded for at least } \\
10 \text { years, if this real } \\
\text { property has been } \\
\text { developed on the basis } \\
\text { of a construction } \\
\text { permit. }\end{array}$ & 1 & 0.0022 & 11,130 \\
\hline Total & 37 & 6.1304 & $14,438,163$ \\
\hline
\end{tabular}

Source: own study.

Table 4

The number, area and price of land plots sold by the Municipality of Krakow between 2012 and 2014 without a tender procedure to the entities listed in Table 3

\begin{tabular}{cccc}
\hline Period & Number of plots & $\begin{array}{c}\text { Area of land } \\
(\text { ha })\end{array}$ & $\begin{array}{c}\text { Total price for disposal } \\
(\text { PLN) }\end{array}$ \\
\hline 2012 & 7 & 2.3876 & $12,537,554$ \\
\hline 2013 & 25 & 3.5968 & $1,837,263$ \\
\hline 2014 & 5 & 0.1460 & 63,346 \\
\hline Total & 37 & 6.1304 & $14,438,163$ \\
\hline
\end{tabular}

Source: own study.

After the expiry of the right of perpetual usufruct, liabilities connected with the land shall not expire and will continue to encumber the real property owned by the former perpetual user. The relatively small number of transactions involving the sale of real estate to perpetual users is due to the fact that this group includes real properties which, without proper grounds, could not be subjected to transformation under the Act on the transformation of perpetual usufruct into ownership.

Eight cadastral parcels were sold to churches without a tender procedure, with a total area of 0.4309 ha. This mode is used only when real properties are sold for religious purposes. Doubts are raised when a multi-purpose facility, which additionally performs other functions (e.g. educational, 
charity, residential, museum) is built. There are no regulations which would specify the extent to which an object sold for religious purposes may also perform other functions.

In the analyzed period, only one plot with an area of 0.0022 hectares was sold to the lessee. In this case, it was possible to apply the procedure without a tender based on optional exemption from the tender by the Krakow City Council, pursuant to Art. 37 Section 3 (Act, 1997).

\subsection{Disposal of residential premises for the benefit of their tenants}

Disposal of real property without a tender procedure has wide application in the case of persons who are entitled to a priority right in the acquisition of public property. This category includes tenants of residential premises, who in the analyzed period purchased about 2.8 thousand of such premises, in most cases with a $90 \%$ discount on the price. The sale of residential premises to their tenants is a continuation of a policy adopted many years ago, which includes the privatization of municipal dwellings. Granting such high discounts also occurs in other large Polish cities, e.g. in Szczecin (SAWICKA 2012).

Tenants have priority in purchase only if the lease was concluded for an indefinite period. The right of priority in purchase is executed when the public property owner decides to sell the property. The public property owner is then, pursuant to article 34 section 4 (Act, 1997), obliged to notify the persons entitled by virtue of this provision of their entitlement to priority in purchasing the property. However, the priority itself does not offer grounds to bring proceedings seeking an order to make a declaration of will, if the owner is not willing to dispose of the property. The holder of the priority right may exercise his priority provided that he or she submits an application for the purchase of the premises within the period specified in the notice (ŹRÓBEK et al. 2012).

The Municipality of Krakow has been selling residential premises in accordance with the applicable provisions of law (Act 1994, Act 1997), as well as pursuant to resolution No. XLVI/568/08 of the City Council of 11 June 2008 on the rules for disposing of residential premises owned by the Municipality of Krakow and determining the terms for granting a discount and the amount of interest rates (Resolution 2008).

When selling premises, a share in the common areas is defined in fractions corresponding to the ratio of their usable area together with the area of their auxiliary premises, to the total usable area of all premises together with their auxiliary premises. The basic step is to draw up a documentation allowing separate ownership of the premises to be established (BYDŁOSZ, PARZYCH 2010).

In the analyzed period, the Municipality of Krakow sold 2,505 residential units for a total price of approx. 56.9 million PLN (cf. Table 5). This amount contains a discount of $90 \%$ on the price granted by the Krakow City Council.

Table 5

The number of real estate premises sold to their tenants and their price

\begin{tabular}{ccc}
\hline Period & Number of real estate premises & $\begin{array}{c}\text { Total price of real estate } \\
\text { premises (with a 90\%) discount } \\
(\text { PLN) }\end{array}$ \\
\hline 2012 & 985 & $22,533,229$ \\
\hline 2013 & 950 & $21,483,916$ \\
\hline 2014 & 840 & $19,525,650$ \\
\hline total & 2,775 & $63,542,795$ \\
\hline & Source: own study.
\end{tabular}

\section{Surveying and legal problems in the procedure of selling residential units to their tenants}

The most significant surveying and legal problems which impede the process of separating and disposing of real estate premises include:

- in the past, determining plot boundaries along the contour of buildings, as a result of which the plots do not meet the requirements of building plots, and are also deprived of access to a public road,

- in the past, incorrect separation of plots of land developed with multi-dwelling buildings, inconsistently with the boundaries of these buildings, e.g. without taking into account "catwalks" and underground cellars, whose horizontal projection exceeds plot boundaries; 
- while establishing separate ownership of the premises, some of them were sold and some were let for perpetual usufruct;

- incorrect calculation of shares in the common areas of real estate (the sum of the shares is not equal to 1); as a result, following separated premises do not hold shares in the common areas that can be sold together with the premises;

In practice, it happens quite frequently that the sum of the shares in the common areas, from notarial deeds and factual findings, is not equal to 1 . This results from:

- various ways of calculating shares in common areas attributable to premises within the same building (in some cases, auxiliary premises are included in the usable area, and in some cases they are omitted),

- inconsistencies in determining the usable area of a building and of individual residential units (the use of different measurement methods),

- failure to adjust shares in common areas of a real property after the reconstruction or extension of premises (adaptation of an attic), as a result of which the total usable area of the premises has changed.

Over the years, the successive separation and sale of residential units initiated by the State Treasury and then continued by the Municipality of Krakow as its legal successor, was based on data regarding the surface area of a building prepared by the building administrator, which proved to be incorrect. The shares attributable to individual owners do not reflect the proportion of the area of their premises to the total area of all premises. In the case of incorrect surveying and legal status of a real estate, which impedes further disposal of such premises, the Krakow City Council, in its resolution (Resolution 2008), excluded residential units owned by the Municipality of Krakow from sale until the status has been regulated, and in the case of proceedings regarding an adjustment in the number of shares which belong to individual premises within the common real property, until the proceedings have finished.

However, due to numerous complaints and protests of tenants interested in purchasing premises, on 19 December 2012, Krakow City Council amended the resolution allowing for the possibility of selling residential units in cases where the Municipality of Krakow has a share in the common property, and the solutions presented to the housing community in order to regulate the incorrect surveying and legal status of the property or adjust the number of shares in the common property belonging to the premises have not been accepted. In such a case, the sales of premises are carried out until the shares in the common property owned by the Municipality of Krakow have been exhausted. However, this solution applies to relatively few real properties, as in most cases, there is a deficit of shares in common areas which should be sold together with the premises.

The condition for continuing the process of separation and disposal of premises in a given real property is eliminating surveying and legal inconsistencies via:

- appropriate, in terms of surveying, separation (consolidation) of a plot of land developed with a multi-dwelling building,

- the adjustment of the incorrect numbers of shares in common areas belonging to the real estate premises in the form of an annex to the notarial deed.

If some of the premises in a building have been sold, the possibility of subdivision (consolidation) requires the consent of all the owners of the premises (housing community), which, in practice, is extremely difficult, and often even impossible. Having regulated the surveying status, the next step is to adjust the incorrectly specified shares in common areas. The new adjustment, as in the case of real estate subdivision, requires the consent of all the owners of the premises - pursuant to the wording of Art. 3.7 of the Act on the ownership of premises. The Act does not provide for any sanctions for those who did not express their consent, nor for a possibility to eliminate inconsistencies in a different way.

\section{Conclusions}

1) In the period of 2012-2014, the Municipality of Krakow disposed of a total of 259 cadastral parcels with the total area of 10.2237 hectares without tender procedures, where 207 plots were sold and 52 plots were let for perpetual usufruct. The resulting income amounted to approx. 24.2 million PLN.

2) Despite the overwhelming number of land plots (225) disposed of in order to improve land use conditions of adjacent real estates, their total area of 4.1131 ha is smaller than the area of 37 plots 
disposed for other purposes (including for the State Treasury, churches and entities managing special economic zones) amounting to 6.1304 hectares.

3) The mode of disposal without a tender procedure is applied most often in selling real estate premises to their tenants. In the study period, 2,775 residential units were sold for a total amount of approx. 63.5 million PLN. This amount took accounts for a discount in the price of residential units of $90 \%$ granted by the Krakow City Council.

4) In the process of separating and disposing of premises, there are numerous surveying and legal problems resulting from faulty actions in the past, the elimination of which requires the cooperation and consent of owners of premises in the given building which had already been separated and sold. Due to numerous difficulties in obtaining the approval of a housing community to eliminate surveying and legal inconsistencies impeding the continuation of the disposal process, the following regulations should be considered:

- to enable the subdivision (consolidation) of cadastral parcels ex officio, regardless of the findings of a local plan, if these activities are necessary to identify the subject of separate ownership of residential property, or when the plot under the building does not meet the requirements of a building plot,

- to oblige the owners of separated premises (members of a housing community) to adjust incorrect shares in common areas belonging to the real property premises. The owners of premises and the owner of the remaining part of the property should be obliged to start negotiations in determining the new number of shares in the common property, as specified in Art. 3.3 of the Act on the ownership of premises. Failure to start negotiations within a specified period would result in making the adjustment by way of administrative law. Taking appropriate actions would enable the gradual separation and subsequent disposal of residential units in the building

\section{References}

BydŁosz J., PARzYch P., 2010, The Practical Aspects of Separate Flat Ownership, Study and Materials of the Real Estate Scientific Society, Vol. 18, No. 4, pp. 23-31.

Gdesz M., TRembecKA A., 2013, Public Real Estate Law, Gall, Katowice, p. 266.

JaWorski J., PrusaczyK A., TUŁodzIECKI A., Wolanin M., 2009, Commentary on the Real Estate Management Act, CH Beck, Warsaw pp.201.

SAWICKA D., 2012, Selected Problems of Management of Municipal Residential Properties on the Example of Szczecin, Study and Materials of the Real Estate Scientific Society, Vol. 20, No. 4, pp. 147-155.

Resolution No. XLVI/568/08 of the Krakow City Council of 11 June 2008 on the rules for disposing of residential premises owned by the Municipality of Krakow and determining the terms for granting discount and the amount of interest rates, Official Journal of the Malopolska Province of 2008, No. 566, Item 3721 , as amended.

The Act of 24 June 1994 on the ownership of premises, Official Journal of 2000, no. 80, item 903, as amended.

The Real Estate Management Act of 21 August 1997, Official Journal of 2014, item 518, as amended.

The Act of 19 December 2008 on public and private partnership, Official Journal of 2009, No. 19, Item 100, as amended.

The Act of 24 April 2009 on investments in regasification terminal for liquefied natural gas in Swinoujscie. Official Journal No. 84, Item 700, as amended.

The Act of 29 June 2011 on the preparation and implementation of investments in nuclear power facilities and related projects, Official Journal No. 135, Item 789, as amended.

The judgment of the Supreme Court of 5 July 2006, ref. No. IV CSK 98/06, LEX No. 459229, the judgment of the Supreme Court of 6 March 2009, ref. No. II CSK 589/08, LEX No. 530697.

ŹRÓBEK S., ŹRÓBEK R., KURYJ J., 2012, Real estate management with a commentary on selected procedures, Gall, Katowice pp. 127. 